\title{
Entertainment-Retail Centres in Hong Kong and Los Angeles: Trends and Lessons
}

\author{
CLARA IRAZA' BAL \& SURAJIT CHAKRAVARTY \\ School of Policy, Planning and Development, University of Southern California, Los Angeles
}

\begin{abstract}
This paper examines the evolution and recent trends in the design of Entertainment Retail Centres (ERCs) in Los Angeles and Hong Kong. Most of the literature on spaces of consumption and leisure deals with economic reasons for the development of these spaces, and with the social, cultural, and political implications of the phenomenon. There are limitations to this approach that this study addresses. First, there has been a lack of attention to processes of globalization in the analysis of these spaces. Furthermore, a largely US-centred approach has left out an understanding of the significance of the ERC phenomenon in other societies. Secondly, the literature lacks a sufficient appreciation of the particularities of urban planning and design associated with ERCs. A body of work addresses the issues of the organization of space within the mall, and its architectonics. However, these studies are by definition limited to the complex, and not oriented towards the urban setting. This paper seeks to address these gaps by moving towards an understanding of the relationship of entertainment retail spaces to their urban and glocal contexts. It considers ERCs not only for the construction of economics, but also of urban, social, and cultural forces, and simultaneously as agents for the mediation of these forces in the built environment of localized places. The analysis is organized along four related themes-land use, transportation, urban design, and consumption patterns. The conclusion offers lessons that can orient both these global cities' trajectories and those of the cities that follow in their footsteps.
\end{abstract}




\section{Introduction}

A recent news article (Saunders, 2007) announced 'the death of the American mall'. A trend recognized in studies by the Urban Land Institute, the Congress of New Urbanism, and the International Council of Shopping Centres, many of the US's 2000 malls are dead or dying, and only three have been built since 2005. However, the Council expects that at least 52 outdoor developments will be opened between August 2007 and 2009. This trend is particularly noticeable in Los Angeles. Meanwhile, China, on the other hand, seems embedded in a frenzied mall-building boom. By the end of 2003, its major cities had 236 shopping centres, 94 more than a year before (Leibowitz, 2004). Hong Kong has built several mega-indoor malls in recent years, while some traditional outdoor market streets are menaced with destruction (Smith, 2007), a trend perceivable in other Asian cities as well. Evidently, as consumerism expands around the world, the shopping mall International Planning Studies typology is in flux, and while architectural styles may not be converging across cities, a greater combination of entertainment and retail options seems to be the common norm. Whether indoor or outdoor, the newer versions of shopping malls whose programmes combine entertainment options with more conventional retail ones are becoming known as entertainment-retail centres (ERCs) (Russell, 1997; Zukin, 1998; Davis, 1999; Beyard, 2001). ERCs aim to boost combined sales per square foot of leased floor area from both entertainment and retail markets by offering a convenient and diverse shopping 'experience', which seeks to 'amuse as well as sell' (Russell, 1997: 90). ERCs treat entertainment and retail uses as compatible services rather than separate land uses, and builds on their complementary nature. They are a complex socio-economic phenomenon because of the issues of location, access, design, and consumption patterns associated with them. In the 'network' view of cities (Castells, 2000, 2005; Sassen, 1991, 2000; Taylor, 2003), ERCs play an important role as points of concentration of global capital and cultural production. As such, large-scale ERCs have become a frequent occurrence in top-tier 'global cities' and are showing increasing incidence in cities around the world. In an ever more globalized world, ERCs are becoming emblematic of the ever greater turn in contemporary cities for serviceoriented economies and the growing relevance of consumptive- and leisure-oriented urban cultures (Fainstein \& Stokes, 1998; Fainstein \& Judd, 1999).1 Hong Kong and Los Angeles represent avant-garde examples of these trends in their respective continents and the world at large (Beaverstock et al., 2000; Smith \& Timberlake, 2002). Through a comparative study of ERCs in these two global cities, we examine how imperatives of globalization, socio-cultural factors, and physical urban conditions are affecting and are affected by the creation and transformation of these spaces.

Within the vastly different contexts of the two cities, we are interested in understanding processes of convergence 2 and divergence of urban design and planning practices, their contextual factors, and their implications. We also provide insights about the role played by local factors in mediating the influence of globalization. As many other cities around the world follow the development paths of Hong Kong and/or Los Angeles, it is important to critically examine their trends to draw lessons that can orient both these global cities' trajectories and those of the cities that follow in their footsteps. Therefore, the research questions driving this work are: How does the development of entertainment- retail centres compare in these cities since the midtwentieth century? What are the convergent or divergent trends of the planning and design of ERCs in these cities?

How are these connected to consumptive patterns in both cities, including those related to the quests for self and city identity? And what policy, planning, and design recommendations can be made regarding the future development of ERCs in both cities so that they maintain or enhance their economic and cultural attractiveness? The analysis is driven by four major themes: land use, transportation, urban design, and consumption patterns.

There are two main lessons drawn from this comparative study. First, evidence suggests that globalization does not simply homogenize practices and values, as a large part of these cities' morphological and cultural evolutions have been ultimately path- and context dependent. The second is that whereas Hong Kong was catching up with the American mall phenomenon in the 1960s, it is now leading Los Angeles in the design and development of ERCs when we account for the need to move towards more 'smart-growth' practices, such as planning for mixed use, encouraging public transit and pedestrian friendliness, and thinking strategically about the entire 
city. The study results in recommendations for future urban design, transportation, land use, and city image-making policies related to ERCs, and lessons for designers, planners, city officials, and developers in these two cities and beyond.

\section{Methodology}

Based on qualitative case study methodology, the project employs triangulation of five research methods. They are literature review (including content-analysis of media), site analysis, participant observation, user surveys, and semi-structured interviews. The framework of analysis,which includes land use, transportation, architectural and urban design, and consumption patterns, was applied throughout the different research methods employed. Aside from scholarly literature review on space and identity in these two cities in general; and shopping centres, entertainment, and retail uses, in particular, marketing brochures and internet sites also served as data for content analysis that contributed to our understanding of how ERCs reflect land use, transportation, design, and consumption patterns; and how they are used for image-making by these cities' dwellers and promoters. Historical analysis of ERCs in $\mathrm{HK}$ and LA was performed to document and understand their evolution and current conditions related to land use, transportation, design, and consumption patterns.

Additionally, the physical interface with urbanized areas adjacent to the ERCs and the potential for design interventions were examined. We further studied one representative case study of the most recent typologies of ERC development in each city, which we call the centennial generation: The Grove as Los Angeles's 'lifestyle ERC', and Pacific Place as Hong Kong's 'hyper-dense, mixed-use, transit-oriented ERC'. We used participant observation in both cities to experience and assess the ambience and urbanism of the ERCs, taking notice of who visits ERCs (age, gender, ethnicity, class, etc.), for how long, what are the purposes of the visits, what retail and entertainment elements are more (or less) patronized, and how do the subvariables studied (related to land use, transportation, urban design, and consumer patterns; refer to tables for the full list) influence their experience of the ERCs. We collected more than 60 user opinion surveys administered online to people who have visited ERCs in both cities. The subjects were sought in students' associations at University of Southern California (USC) and University of California, Los Angeles (UCLA) and from among other acquaintances that have experienced ERCs in HK and LA. These subjects were in turn asked for referrals to other subjects, who were then selected using the snowball sampling technique. This survey was designed to assess the perceptions of visitors regarding their experience of using ERCs in both cities. The sample has a bias for college students, but we have partially readdressed this bias by using other research methods and by posing questions regarding the general use of malls in addition to individual experience. 3 We also interviewed a dozen survey respondents using a semi-structured format for each interview, inquiring further about some of their survey responses and about our own interpretation of the variables and sub-variables studied in each city. We drew on face-to-face and phone semi-structured interviews with several scholars who have done research and fieldwork in either Los Angeles, or Hong Kong, or both. Surveys and interviews were used to validate information gathered with other research methods.

\section{Hong Kong and Los Angeles: Vastly Different, Uniquely Similar}

These seemingly disparate cities are both globally important centres of consumption, and nodes of high capital and information flows. In analysis presented by Beaverstock et al. (2000: 127), both cities are counted among the 'alpha' cities of the world. The designation denotes the 'level of service provision' by firms in 'accountancy, advertising, banking/finance, and commercial law'. Only 10 out of 55 'world cities' have been classified as 'alpha' cities. With only three cities in the first tier-London, New York, and Tokyo - the authors also analyse linkages to London based on the services provided by London-based firms located in the other cities. Although Hong Kong is found to have a stronger link to London, Los Angeles is also in the second tier, based on this relationship. Also, according to a study based on air travel data presented by Smith and Timberlake (2002), Los Angeles and Hong Kong hold 7th and 8th ranks, respectively (in 1997).

Here, the rank represents relative 'power', defined as the 'ability to dominate the whole system across spheres' (Burt \& Schott, cited in Smith \& Timberlake, 2002: 123). This broad definition is loosely associated with air travel by the authors. On these bases and other various standards 
based on capital, information, and human flows, both cities in question are among the most influential in the world and quite close to each other in global ranking.

Both Los Angeles and Hong Kong have very strong consumer cultures. According to the latest Consumer Expenditure Survey results from the Bureau of Labour Statistics of the US Department of Labour (2004), for the categories of retail and entertainment specifically, Angelinos spent $19.72 \%$ of their budget, as follows: food outside home $5.62 \%$, and other various categories $14.1 \%$ (entertainment $4.8 \%$, apparel and services $4.2 \%$, miscellaneous $2.2 \%$, personal care products and services $1.3 \%$, alcoholic beverages $0.9 \%$, smoking products $0.4 \%$, and reading $0.3 \%$ ). Conversely, according to the latest Consumer Expenditure Survey results from the Government of the Hong Kong Special Administrative Region (2005), Hong Kongese, on their part, spent $31.92 \%$ of their budget in retail and entertainment, as follows: meals bought away from home $16.86 \%$, and other various categories $15.06 \%$ (durable goods $5.50 \%$, miscellaneous goods $4.78 \%$, clothing and footwear $3.91 \%$, and alcoholic drinks and tobacco $0.87 \%$ ). In sum, (and bearing in mind the different data periods) for the categories of retail and entertainment, Hong Kongese spent $11.24 \%$ in meals bought away from home and $0.96 \%$ in other various categories as compared with LA. For the categories outside of retail and entertainment, on the other hand, Angelinos spent approximately $80.27 \%$ of their budget, and Hong Kongese spent $68.08 \%$, including $24.34 \%$ in housing, $29.61 \%$ in transportation, and $3.31 \%$ in food at home as compared with LA.4

Further, both cities are home to large multicultural populations. Significantly, they are also centres of large entertainment industries, including film, television, and music. These industries are engines of cultural production with wide regional spheres of influence. The large populations in both cities interact with media representations that construct an imagined relationship between the cities. The relationship, however, is more manifest in Hong Kong and not so much in Los Angeles, where it is limited to the expatriate population. In other words, the allusion to symbols (e.g., landmarks, place names, etc.) of California (and in particular of Los Angeles) is more frequent in Hong Kong, than vice versa. Some of the prominent signifiers in Hong Kong include Westwood, Bel Air, Hollywood, and California itself, denoting different places. In terms of urban form, however, the two cities are poles apart. Whereas Hong Kong is characterized by high density and reliance on public transportation, Los Angeles represents sprawl and cardependence. These remarkable differences notwithstanding, the two cities show several significant similarities in their approach to designing entertainment-retail spaces. The similarities are not typical of these two cities alone. It is the vast contextual differences that separate these two cities, however, what make the ERC similarities all the more significant and worthy of inquiry.

\section{Evolution of Entertainment and Retail in the Two Cities}

Both Los Angeles and Hong Kong have inspired a vast body of work on all aspects of city planning. This paper deals with only a specific part of these complex cities. We are looking at the historical evolution of entertainment-retail centres in the context of the variables of land use, transportation, and urban design, along with associated socio-economic and cultural trends related to consumption. Additionally, we are concerned with how these cities evolved as centres of consumption and entertainment, and how these functions, mediated by their entertainmentretail spaces came to be a major determinant of their very identity.

The conceptualization of the entertainment-retail centre follows the observed trend, in recent years, of the increased cohabitation of entertainment (including spaces for social congregation and interaction) and retail activities in new spaces for leisure and consumption (Goss, 1993; Shillingburg, 1994; Zukin, 1998; Beyard, 2001). Our concern is with large-scale developments that have followed the conventional enclosed shopping mall as entertainment destinations in addition to serving retail functions. It could be argued, that to some extent, shopping itself is a form of entertainment. We are, however, concerned with sources of entertainment that are distinct from retail. The entertainment component of these destinations may involve various kinds of spectacle including, but not limited to, nightclubs, cinema halls, theatres, restaurants, architectural themes, rides, live music, and other special events. This tendency to create an economy of scale in terms of clientele also has political implications. Most significantly, it brings certain activities that were traditionally part of the public sphere into the private realm. 
Additionally, the globalization of the economy has led to the creation of consumptive societies5 (Goodwin et al., 1997), and the propinquity of entertainment and retail in fast growing metropolises has facilitated this process. The resulting hybrid urban programmes and forms of ERCs are a product of the interaction of local place-based characteristics with less placegrounded spatial arrangements designed for a globalized economic agenda and cultural taste.

Our research findings (based on a framework of four variables-land use, transportation, urban design and consumption pattern) suggest that since the 1960s there was a convergence in retail centre styles in the two cities' studied, with Hong Kong following trends observed in Los Angeles (and the United States in general). Large indoor-shopping centres, which had become common in the United States were replicated in Hong Kong capturing both the climate and the economies of scale. This, however, was followed by a divergence of styles in the late 20th century with each city developing in accordance with its own spatial, political, cultural, and market contexts. Whereas ERCs in Los Angeles followed its sprawling growth pattern linked to a freeway system, Hong Kong ERCs tended to become a part of the city's contiguous fabric. At the turn of the new century, a degree of convergence has once again emerged with entertainment and retail increasingly coexisting in the same place and hybrids of earlier styles being created. This new convergence suggests that in post-modern global cities, certain urban processes are becoming increasingly context-free.

In other words, these processes are being defined to a large extent by 'agencies of globalization'-i.e., global capital, information, people flows, and culture (Pizarro et al., 2003) and not solely by local characteristics. At the same time, practices of urban planning and design are far from homogenized between these two cities. At the beginning of this century, Hong Kong's ERC development is leading innovation in the built environment with regards to what are conceived in the US as smart growth policies-compact, efficient, mixed-use, and pedestrianand transit-oriented development models. Conversely, Los Angeles' ERC development is playing closer attention to quality design, taking a subtler approach to the attainment of profitability through the diversification and improvement of users' spatial experiences.

Although there had been shopping centres in the United States in the 1920s and 1930s, it was only in the post-World War II period of construction boom that shopping malls became really popular. Therefore, the phenomenon of malls shares a temporal correlation with suburbanization. The causes of suburbanization, including race and class relations and the rising automobile ownership and dependence, assisted the growth of malls (Longstreth, 1998). Hanchett (1996: 1083) particularly draws attention to the federal tax policies including 'accelerated depreciation' on new construction, which in the mid-1950s made the construction of large structures a lucrative tax abatement strategy for developers. Data on the number of malls in the United States between 1947 and 1960 show that there was a rapid proliferation of both 'regional centers' 6 as well as shopping centres of all scales. In concurrence with Hanchett's hypothesis, a large spurt occurred right after 1954 when the new Internal Revenue Code was passed into law.7 The number of new large regional malls constructed annually rose from 5 in 1955 to 25 in 1956. In the same period the total number of malls constructed annually rose from 104to 156. Jackson (1996) summarizes the causes of rapid proliferation of centralized retail activities in the post-war era and through the 1960s. These include tax policies that allowed retail to precede residential development, availability of cheap developed land at the peripheries of cities, relatively weak land regulations, subsidized automobile travel, and the depreciation of land rent in the suburbs. Cohen (1996) also notes that consumption was glorified in the early post-war years. She also argues that suburbanization nurtured malls by providing cheap locations in the midst of wealthy residents. Her main point, however, is regarding the political effects of the shift of retail activity from town centres to shopping centres. Cohen argues that privatization of retail activity through shopping centres contributed to social segregation and exclusion. Significantly, she also points out that by the 1960 s, malls had already become the 'distinctive public space .... for a new kind of community life' (p. 1068).

The view that shopping centres and more recently entertainment retail centres have substantively compromised democratic public space is shared by other scholars (Goss, 1993; Jackson, 1996; Kohn, 2004; Mitchell, 2003). Cohen (1996) cites court cases from past decades to illustrate the jostle between private property rights and constitutional First Amendment's guarantees of free speech. Although courts have ruled both ways on the issue, the arguments 
from both sides leave no doubt about the malls partially replacing city streets as 'public' forums. As Cohen perceptively points out, the proponents for free speech operating in private centres, are, by their very presence there, endorsing the very institutions that undermine their existence. The issue then is not solely about free speech, but more generally about a 'transformation of the public sphere' (Habermas, 1989). Goss (1993: 19), offering a Marxist critique, calls the modern mall a 'pseudoplace' where developers disguise the 'contemporary capitalist social order' with fac, ades and activities that give the impression that 'something else other than mere shopping is going on'. This need for 'something else' goes a long way in explaining the recent emergence of entertainment- retail complexes.

We can identify two related strands in the literature on spaces of consumption and leisure. The first deals with economic reasons for the development of these spaces, and the second with the social, cultural, and political implications of the phenomenon. Therefore, at the risk of some reduction, malls have predominantly been studied as economic entities with socio-political implications. There are two limitations to this approach that this study would like to address. First, there has been a lack of attention to processes of globalization and trans-national flows of capital and culture in the analysis of these spaces. Furthermore, a largely US-centred approach has left out an understanding of the significance of the ERC as a social product in other societies. Secondly, the literature lacks a sufficient appreciation of the particularities of urban planning and design associated with ERCs. A body of work addresses the issues of the organization of space within the mall, and its architectonics (Chase, 1991; Goss, 1993; Sterne, 1997). This work is useful in understanding how design mediates the cognitive relationship between consumers and commodities. However, these mainly architectural studies are by definition limited to the complex, and not oriented towards the urban setting. This paper seeks to address these gaps by moving towards an understanding of the relationship of entertainment-retail spaces to their urban and glocal contexts. It considers ERCs not only for the construction of economics, but also of physical, social, and cultural forces, and simultaneously as agents for the mediation of these forces in the built environment of localized places. To this end, the study explores the historical trajectories of ERCs' typologies in Hong Kong and Los Angeles to show how different kinds of ERCs are the results of the interaction of a complex set of factors.

\section{Entertainment-Retail Spaces in Hong Kong and Los Angeles}

\section{Los Angeles}

The earlier entertainment-retail developments in the US occurred at the turn of the nineteenth century, between 1895 and 1920, when the downtown entertainment district and the multistoried shopping emporium were created. The earliest forms recognized as shopping centres in the US date back to the 1920s and 1930s (Longstreth, 1998). With a fast industrialization process, the traditional organic street shops were reorganized into formal blocks under the street grid system. Shopping was developed in separated buildings with housing and offices above. This type of development was named the urban block model, or street shopping. Street shopping was usually designed as part of a new town centre. Eventually it became a basic composition form of cities and spread on many 'main streets'.

Suburban and urban regional centres: beginning in the 1950s. In the process of suburbanization during the 1930s and 1940s, a shopping mall type known as the 'dumbbell mall' was created as a fundamental element in the strategies of decentralization. Originally, its basic form consisted of two large department store anchors connected by a series of outdoor pedestrian atrium spaces. It was utilized to reform the fragmented nature of development in both urban and suburban areas (Crawford, 2002). In the 1950s, developers, planners, and architects endeavoured to increase urban density and integrate commerce into community life. The pioneer mall designer Victor Gruen developed a new mall type-the enclosed mall, which grouped everyday retail under covered and climate-controlled central spaces. During the next few decades, the enclosed mall expanded to regional mega malls, suggesting new forms of civic realms. Designers and developers generated several distinctive mall types. Some basic configurations of regional malls in the LA region included: the enclosed mall with atrium built around a dominant centralized space, for example, the Westside Pavilion in Westwood and Santa Anita Fashion Park in Arcadia; the multi-storied, vertical centres, usually located in 
restricted sites or city centres, such as the Seventh Market Place in downtown LA; and the arcade and galleria centres that constitute linear features in suburban areas, such as Glendale Galleria in Glendale and the Galleria at South Bay, Redondo Beach (Maitland, 1990).

The character of these entertainment-retail centres was constituted by standardized products with reproducible features that could be built on any site with adequate space. Most suburban malls are one to three story buildings with a retail space ranging from 80,000 to 125,000 square meters. Typically, suburban shopping centres in Los Angeles are essentially mono-functional (i.e., commercial uses only), are far from the central areas of the city, and are difficult to access without a personal vehicle. The surrounding areas of the development are dominated by nonresidential services, big surface parking, and vehicular roads. The shopping places are inwardoriented and have little connection with the surrounding communities because of their enclosed nature. The outside fac, ades are blank and uninteresting (the centres look like 'big boxes'), and the interior activities are invisible from the street.

Reinvented streets: beginning in the 1980s. New styles of retail and entertainment centres emerged at the beginning of the 1980s. Many projects combined traditional retail with nightlife and dining options. Banerjee et al. (1996) formulated the concept of the 'reinvented street' as a style of ERC. One example is Third Street Promenade in Santa Monica, California. In the 1960s, a section of Third Street was converted into a pedestrian mall, but had turned out to be an unsuccessful project. In the 1980s, the mall was successfully reinvented as the Third Street Promenade, involving a popular mix of activities devoted to movies, recreation, nightclubs, and restaurants. The reinvented street attempted to create a novel walking experience in the midst of a largely auto-dependent urban form. Drawing inspiration from European city centres, the reinvented street turned its very form into an attraction and selling point. However, unlike in Europe, most visitors still drive to this destination and park before walking in the reinvented street. The Promenade is thus surrounded by several parking structures. Another regional example, Old Town Pasadena underwent a similar transformation in the 1980-90s. The ongoing Grand Avenue and Figueroa Corridor projects in downtown LA are now replicating the experience. This idea was so successful that it spurned a whole new generation of entertainment-retail design, which entirely manufactured street experiences.

Invented streets: beginning in the 1990s. Following Banerjee et al. (1996) and Banerjee (2001), we concur that there exists a 'vernacular LA tradition' for the creation of entertainment-retail centres-that of 'invented streets'. Through the 1990s, these newer ERCs transformed the old retail landscape by introducing themed entertainment, new media, and stage settings. CityWalk in MCA Universal Studios is a street set designed from scratch, and offers a mix of specialty stores, signature restaurants, and entertainment options (Soja, 1989, 1996). Another prominent example of invented street is Two Rodeo Drive in Beverly Hills, which is characterized by its European theme, and high-end retail brand names. The success of the reinvented and invented streets and increasing competition between retail destinations ushered a generation of entertainment-retail design based on providing a novel spatial experience through the theming of the built environment (Gottdiener, 1997).

Centennial generation: hybrid, themed lifestyle centres of the 2000s. Facing increasing competition, greater segmentation of markets, and more selective consumers, the programmes of retail destinations were broadened to include compatible activities (such as restaurants and entertainment) with increasing intensity. Recent mixed-use ERCs such as Paseo Colorado in Pasadena, Hollywood \& Highland in Hollywood, and The Grove in Los Angeles, represent new trends of adopting relatively higher density and mixed-use development patterns, creating special cultural nodes, and blending them into the urban fabric. Open to the outdoors, they emulate urban streets and plazas and use thematic architecture. Their form and programme cater to selective market niches by class, lifestyle, and more recently, ethnicity. This is the case of Plaza Mexico, a new ERC in Southern California that emulates a Mexican town both programme- and design-wise, and is very popular among Latinos (Irazábal, 2007a). We call this type of ERCs the Centennial Generation. These centres reconfigure existing commercial space through the recreation of a sense of place to cater to better-defined market niches. To some extent, the centennial generation succeeds in bringing back a lost 'publicness' to the shopping centre. These faux downtowns-also known as lifestyle centres (a name coined by developer Terry McEwen when he built a centre of this type in suburban Memphis in 1987)—continue to 
gain momentum at the national and local level. Lifestyle centres usually mix high-end or culturally fit retailers with hip restaurants and pleasing architecture. Developers explain their success though their convenience, safety, and tailored offerings. The people who patronize them see them as surrogate community centres or town squares (Ramsey, 2003).

\section{Hong Kong}

Hong Kong's trajectory of retail development is closely related to its colonial history under the British government and to its relation to mainland China. From 1530 to 1840, foreign merchants gradually established offices in Macao and Hong Kong as well as in Canton, China. After the liberation of China from the British in 1949, Hong Kong remained as a bastion of the British and was flooded with two million immigrants who brought capital and skills to help establish many manufacturing industries. Between 1949 and 1997, Hong Kong still operated under British rule and served as a gateway to China. In 1997, when Hong Kong was returned to the Chinese government, it had become a world-class commercial centre with many modern skyscrapers, a strong urban infrastructure, and a population of over six million. Today, Hong Kong's reputation as a free market economy with laissez-faire governance is well established. As the largest owner of land in the city, the Hong Kong government is tightly intertwined with developers and large business and financial interests. $\mathrm{Ng}$ (1999: 11) reports that the 'bureaucratic-cumcorporatist' Hong Kong government evolved, in the 1980s, into an institution where the market is the pre-eminent means of governance even though a 'development ideology' underlies plans.

Public financial resources are periodically raised through the auction of land, of which a large part is 'reclaimed' from the sea. $\mathrm{Ng}$ (2005) draws attention to the lack of macro-level strategic planning (p. 123). In effect, 'positive non-intervention' (p. 122) has empowered corporate interests to direct the development of the city to maximize profits. As Lo (1992) points out, however, planning in Hong Kong has played a role in shaping the city, even though the driving motive has been profit-driven private development. In this environment, 'successful' ideas from other parts of the world (for example, shopping centres in the United States) are quickly adapted and absorbed.

Multiuse buildings: beginning in the 1930s. In Hong Kong, shopping has been an integral part of the urban fabric from the very beginning. Liang (1973: 111), in an analysis of land use in Hong Kong, developed a hierarchy of 'business centres'. Liang's analysis reveals that apart from the areas of high-income residential uses, the ground level of almost all the urban land on the Kowloon peninsula is occupied by commercial uses. 'This commercial stratum extends vertically in certain nucleations, like cones, to different heights and extents, depending on the accessibility and spatial distribution of purchasing power' (Liang, 1973). Land use regulations in Hong Kong determined height and bulk for buildings to compensate for the paucity of usable land in the city. Understandably, this resulted in predominantly tall buildings that could multiply floor area ratios, since building horizontally was not an option in a constrained-island geography. Hence, single-storied 'big-box' stores were precluded from the start. In the tall buildings, the share of floor space for commercial use was determined by allocations based on demand of space for particular uses. In contrast, in Los Angeles, the availability of large amounts of undeveloped space created an incentive to sprawl. The market-based use of land in Los Angeles was predominantly horizontal, whereas it was vertical in Hong Kong. Therefore, the availability of land and the regulations in place to manage land were determinant in defining form in each city. However, the allocation of uses was determined by market principles in both cases. The period from 1930 to 1970 in Hong Kong has been described as an era of 'transformation' (McDonogh \& Wong, 2005: 61-88). This period featured the proliferation of 4storied structures. The buildings had commercial use on the first level and residential use on upper floors. In the 1951 Hong Kong Report, the authors highlight the high densities and poor living conditions afforded to the small apartments within these buildings.

The early malls: beginning in the 1960s. In Hong Kong, traditional street retail within mixed-use zones has been the norm, since the city began to grow under British occupation in the 19th century. It was only in the 1960s that shopping malls appeared in the city. Relative to Los Angeles, the phenomenon of the shopping mall came 15-20 years later to Hong Kong, but with a difference. In Hong Kong, malls developed as a part of the urban fabric, not a destination on the outskirts of the city. Malls in Hong Kong were within walking distance of residential quarters and public transport. In 1965, 100 twenty-storied buildings were planned in Kowloon, to be 
funded by Mobil Oil and to house 90,000 people. These buildings were planned to include malls, cinemas, public transport, and other religious and educational public uses (McDonogh \& Wong, 2005).

Compared with Los Angeles, Hong Kong's shopping developments are more mixed-use, directly linked with housing, entertainment, and transit. Most developments have only happened in the past 40 years. In the 1960s, Hong Kong was transforming from an industrial colony to a financial centre of Asia. The Ocean Terminal shopping mall opened in 1966 marking the beginning of the first generation of Hong Kong's shopping centres and of the greater 'Hong Kong's malling' phenomenon (So, 2000; Lui, 2001). In the following years, the Ocean Terminal became a part of a larger complex, the Harbour City shopping mall. Lui (2001: 33) calls Ocean Terminal 'an icon of the new times'. At that time 'shopping was still a chore, not the unofficial national sport it is today' (Lim as cited in Lui, 2001: 34). The early malls were exclusive by price and aimed at attracting tourists. Lui (2001) underlines the cultural and symbolic significance of the Ocean Terminal mall as the site for socialization into a consumer culture, a space to 'explore the freedom of consuming' (Lui, 2001: 40), by observation of elite behaviour and by discovering one's consumer identity through window shopping.

Stratified malls: beginning in the 1970s. As Hong Kong became an entrepot for Chinese manufacturing, a large number of shops and shopping centres opened in different parts of the city. A stratification of shopping centres emerged, defined by brands, status of merchandise on sale, and the social background of clients (Lui, 2001: 39): 'These shopping malls belong to a new generation and are well stratified according to the status of shops and spending power of their customers'. Additionally, there was a general tendency of integrating shopping with business and housing, not only in the main urban areas but also in the new towns (Bristow, 1989). This requirement of planning for malls is still prevalent and extends to public housing projects as well. The government policy to mix housing with retail changed the socio-economic status and living conditions of public housing residents. After some of these projects were built, public housing residents were no longer seen as poor working class people, but rather as more affluent individuals who could afford high consumption (Liu, 2001). Lui lists City Plaza and the Landmark shopping centres as prominent examples of malls in the topmost category of the new evolving hierarchy that had malls 'penetrating almost every corner of Hong Kong' (2001: 40).

Efforts were also made to link new developments to appropriate public transportation systems, including bus routes and the metro. The Landmark, for example, is located above one of the busiest metro stations. The most significant impact of the stratified malls was to make shopping an everyday activity for everyone. Stratified malls transcended both class and geography by being included in public housing and in peripheral new towns. This period paved the way for the most contemporary style of development, entertainment-retail centres that have become the hubs of consumption and social life, reflecting what Lui calls the 'dominance of consumerism' (Liu, 2001: 40).

Centennial generation: transit oriented ERCs beginning in the 1980s. Since the late 1980s, a new generation of ERCs came into being and established new categories according to the status of shops and purchasing power of the new customers. More gigantic ERCs such as Pacific Place, Dragon centre, Times Square, Plaza Hollywood, and Festival Walk were built. Each of these shopping centres is composed of a group of high-rise towers with housing, offices, and hotels on an ER podium. A variety of venues such as retail, entertainment, commercial, and sports clubs are included in such podiums, which support an increasingly sophisticated urban life. Compactness draws the flows of people through an intensive network of multi-modal circulation. Many developments are prefabricated for cost-effective construction. The structures are repetitive, coded under planning restrictions and real estate market demand. Although this is true of the general layout of ERCs, it should also be mentioned that the designs, especially the main fac, ades and interior spaces, aspire for a unique sense of place through the use of decoration, art and media installations, lighting, views, etc. The ERCs in this category contribute to shape the current consumptive and entertainment culture of Hong Kong. Each of the examples mentioned above contain a significant entertainment component. Although, in most cases, these ERCs contain high-end retail opportunities, some relatively affordable brands can also be found to attract diverse consumers from the steady stream of commuters passing through them. These malls, with their convenient furnishings, entertainment options, and window-shopping opportunities, have become the pre-eminent points of social rendezvous, 
especially for the youth.

In the next section, we compare one case study from each city that represents its most recent ERC generation to elucidate more explicitly the similarities and differences that exists between the typologies, as well as the implications for the future of ERCs development in both cities. We consider The Grove, which is a typical example of the lifestyle centennial generation in Los Angeles, and compare it with Pacific Place, of Hong Kong's hyper-dense, multiuse, and transitoriented style.

\section{Comparing Los Angeles's and Hong Kong's Centennial Generation ERCs}

The comparison of a case from each city's contemporary style of ERC is made along the variables of land use, transportation, urban design, and consumption patterns. We observe that in the two cities, which are very alike in their adherence to product marketing and sales management aspects of goods in the global economy, and where populations are highly socialized into sophisticated and pervasive consumerism, the styles of ERCs have evolved along different historical trajectories. The impact of globalization is not to completely homogenize urban form, as key aspects of previous ERC styles remain in both cities. Also, the influence of local contextual factors (climate, geography, demography, urban lifestyle, building traditions, and regulatory systems) is paramount in determining urban form. The current most popular typologies of ERCs in Los Angeles and Hong Kong, which we call centennial generations, not only are different from each other, but also different from previous retail and entertainment spaces in their own cities, representing a particular historical moment in the evolution of their typological trajectories that create new design synthesis with a combination of old and new elements. We suggest that, whereas Hong Kong followed Los Angeles (and in general the United States) in the 1960s, now Los Angeles can continue offering inspiration, but has important lessons to draw from Hong Kong's ERC design.

\section{LA's Lifestyle ERC: The Grove}

Land use. The Grove is a boutique outdoor ERC located across the street from the historic Los Angeles Farmers Market. It features a combination of small retail, large chain stores, a 14screen cinema, and outdoor attractions such as a dancing fountain, a lawn (where live music groups perform), a free streetcar, and themed streetscape. It opened in 2002 and was designed by Caruso Affiliated to resemble 'the great Los Angeles boulevards of the 1930s and 1940s' (Caruso Affiliated, $2006 \mathrm{sic}$ ). Historical accuracy, however, was not the prime concern in recreating shop fronts of the 1930s at The Grove. The scheme of (false) fac,ades and other effects at The Grove, including a trolley running quarter-mile circles around the site, does simulate an older period. In a region of scant architectural unity, even a faux attempt at harmony is an attractive departure, as proven by the 18 million people who visited in the first year alone (Caruso Affiliated, 2006). However, the horizontal mall with two to three stories hardly does justice to the stated model of the boulevards of the 1930s and 1940s. Ironically, the mall gives its back to the real Los Angeles streets and to a park besides it. It is designed around a central pedestrian core and leaves its parking facility and blank back fac, ades of the stores facing the street. The ratio of width of the inner pedestrian street to the height of the abutting buildings and the style of fac, ades and streetscape at The Grove demonstrate the attempt to create the ambience of a European central city. In keeping with typical images of European urbanism, some cafe's are allowed to spill over into the circulation area. The space often gets pretty crowded and a certain degree of random social interaction, as prescribed by Jacobs (1961) in her review of successful urban places, is achieved. However the pre-eminence of consumerism over flanerie is a noticeable difference between The Grove and most European comparisons. Moreover, the bulk of the buildings, the use of false fac,ades, the giant chain stores (e.g., Apple, Gap, Barnes and Noble, and Cheesecake Factory, to name a few in different product categories), and the lack of mixed uses (most notably the lack of housing) make European pretensions rather superficial.

Transportation. To its credit, The Grove is not completely cut off from public transportation. This is largely due to the fact that it was created well inside the thickly populated parts of Los Angeles and public bus lines were already in place. No new lines have been added by the Metropolitan Transit Authority on account of the development of The Grove. There are no 
studies of transit ridership of The Grove clientele. However, if the usually packed eight-level 3,500 -space parking is any indication, the average $\$ 126$ shopping is rarely carried away in public buses. There is no metro station in the vicinity of The Grove, and there has been no attempt to run shuttles to the nearest metro station, or to install a taxi service specially for the shopping centre's needs, or to have new bus lines (in collaboration with the existing Transit Authority or independently) service the primary catchment area of the ERC. Transportation connections exist but are used primarily by the lower-income workforce of The Grove. Clients are encouraged to use cars (3,500-space parking structure, free parking for two hours with validation, and only $\$ 2.00,3$ hour-parking cost). The L-shaped block on the northern side of the site is the parking structure, which takes up nearly half of the site area. It is also the tallest structure on the site. The attraction of The Grove has caused sensible problems of traffic gridlock around the area at all times, and most particularly during weekends. This condition has generated neighbourhood complains.

Design. As compared with the generations of shopping centres before, The Grove deserves credit for attempting to buck the trend and create a 'sense of place' (especially with the help of sophisticated stage-setting design and special events) rather than a merely functional mall space. Its popularity is evidence of its design success. From a marketing perspective, The Grove ranks highly for its popularity. In terms of its design, The Grove is a space of hybridity. There is hybridity between the typical American mall and the idyllic European city centre. The ease of purchase, grouping of brands (across product types) specifically for a certain class of consumers, and a large garage for parking makes The Grove quintessentially American. This character is, however, dressed up in a design fac, ade that attempts to replicate the outdoor walking and public space experiences such as those of a typical European city centre. There is also hybridity between various earlier generations of malls and shopping centres in Los Angeles. The Grove functions as a regional centre in terms of reach and activity. At the same time, the place also has the themed affects of a typical Los Angeles 'invented street'. Further, there is a hybrid character to the relationship between private and public at The Grove. Although it was conceptualized and executed by private interests, the project involved a well-publicized effort of public engagement in its planning phase. The extent of this effort was not legallymandated, but rather a strategy of the developer to minimize discontent and maximize publicity. Finally, the use of architecture and design itself as a source of entertainment (in the same vein as Disneyland or Las Vegas' Strip; see Iraza'bal, 2007b) is the next level of hybridity. This includes a musical fountain with an adjoining children's play area, and pastel-coloured buildings. The effect of this invented urbanism is completed with sidewalk cafe's and an electric cable car, from where one can appreciate the façade-deep architectural themes. A well-enclosed lawn, anchored by an ice cream parlour on one side and a water pond on the other, provides a popular place for music shows.

A significant feature of the design of The Grove is the preservation of the historic Farmers Market. The market enhances dimensions of history, authenticity, and community while adding dozens of more affordable dining and shopping options to the site. The Farmers Market, which dates back to 1934, had evolved into a veritable landmark in the Los Angeles landscape by 1941 , when it was renovated. Now, the market has been lent a new wave of popularity because of the large market attracted by The Grove, which abuts the property and is internally connected by the main pedestrian path and the cable car running along it. The architecture and uses of the Farmers Market have not been significantly modified and it is allowed to operate as a distinct yet complementary node. A similar degree of interaction was, however, not sought with the public park, which is just across the eastern street from The Grove and remained cut off from it. Lastly, The Grove has generated gentrification of the area, with expensive and dense residential developments sprouting around it. Without changes in the transportation infrastructure of the surroundings or the driving habits of Angelinos, the new residents are posed to aggravate the existing traffic problems.

Consumption patterns. There is no question about the success of The Grove, with reported 'sales per square foot that are $40 \%$ above the industry average' and with numbers of annual visitors surpassing those of Disneyland (Caruso Affiliated, 2006). There is also little doubt regarding the exclusive nature of this upscale retail space. According to the website of The Grove's developers (Caruso Affiliated, 2006), the average local customer visits 34 times a year, and $92 \%$ of the times leaves with an average purchase of $\$ 126$. The local customer base for this impressive consumption is drawn from some of the upscale neighbourhoods in Los 
Angeles, as evidenced by the residential zip code of customers. Although The Grove cannot avoid the charge of being somewhat exclusive and elitist (because of the price and type of commodities offered, where even the movie tickets are more expensive than elsewhere), its tremendous popularity suggests that the design has managed to create a new form of public space. It is still privately owned (as shopping centres before it), but includes uses beyond simply shopping. As described above, it has taken the next steps towards evolving past mall design into an entertainment-retail destination. Everyday, there are two to four special events in The Grove ranging from sing-alongs to readings, including a weekly meeting of a 'Nikewomen run/walk/jog' group. The Grove is also offered as setting for special events and for filming, not surprising for a city where the media industry is paramount and is always searching for interesting locations to shoot. It has to be noted that the popularity of The Grove is partially due to the general paucity of good quality public space in Los Angeles. The brilliance of the Grove is that it creates at least the illusion of vibrant civic space in a city that has hardly any to speak of. The developer has consolidated the success of the model by creating new 'lifestyle centers' in other location of the region. Most significantly, the next generation of ERCs will include an increasing proportion of residential use. The next generation also promises to be larger and increasingly diverse in its offerings. The Santa Anita Park in Arcadia, California, for example, will incorporate an existing racetrack.

\section{Hong Kong's Hyper-Dense, Multiuse, Transit-Oriented ERCs: Pacific Place}

Land use. Pacific Place is a massive mixed-use complex in Hong Kong's commercial centre. The site includes three five-star hotels (Marriot, Shangri-La, and Conrad), apartments, office space, conference centre, and shopping mall. The high-rise design has four buildings of 40 to 60 floors. The project was built in three phases beginning in the late 1980s with the first mall opening in 1988. The most recent building was completed in 2004 (Emporis Buildings, 2004). The shopping centre at Pacific Place has five floors with plenty of circulation space, relatively high-end shopping options and a four-screen cinema theatre. It is crowded round-theclock, thanks to the neighbouring mixed uses and its location above the intersection of two subway lines, with an exit opening directly inside the mall. This is Hong Kong's strategy for paying for its metro stations-allowing ERCs to be built directly above them. The developers pay for the station and in turn receive a ceaseless flow of pedestrians walking through their mall. Another huge distinction is density. The Grove has 585,000 square feet of floor area on a site of 17.4 acres. In comparison, Pacific Place has 5,000,000 square feet of floor area on only 6.5 acres. This high density, also sustained in the surroundings of the ERC, ensures both viable public transport and economic vitality for the ERC.

Transportation. The integration with public transportation between the two ERCs is an obvious difference. On the website of The Grove, directions are offered for cars approaching from the various freeways. On the Pacific Place website, conversely, directions are for access through subway, buses, and taxis. In fact, Pacific Place with all its mixed use and five million square feet of floor area has only 500 parking spots, conveniently located underground, whereas at The Grove, the above-ground parking structure is the bulkiest of the complex. The entire Pacific Place, like the rest of the city, is designed around public transit and pedestrian accessibility and comfort. In Hong Kong, the activity of flanerie has shifted to climate-controlled indoor environments. The air-conditioned subway system, malls, and walkways attract pedestrians for 'hanging out' as well as for commerce. Hong Kong's transit-oriented ERCs are a result of strategic planning and public-private partnerships. ERCs, as seen in Pacific Place and other similar centres (such as the International Financial centre or IFC Mall and Skywalk) are a way of life in Hong Kong because they are fully integrated into the functions of everyday life and the regular pathways of many pedestrians. Hong Kong's strategy is not to make malls a destination, but rather to place them on the way to every destination. This is how this newest category of entertainment-retail has evolved in the peculiar context of Hong Kong and has become a welladjusted vernacular style.

Design. Pacific Place is comprised of three buildings, which contain a conference centre, 270 residential units, office space, and three hotels. The Pacific Place One houses 860,000 square feet of world-class office accommodation on 36 floors, each providing approximately 20,000 to 22,000 leasable square feet. In addition, Pacific Place Two includes 700,000 square feet of Grade A office space on 27 floors. The newest addition, Pacific Place Three, is a 38-storey 
Grade A office tower with 620,000 square feet, located above the Admiralty MTR station (Swire Properties, 1999). The complex is located on the site of the former British barracks. 'The mall. . . is a podium for top hotels and is flanked by the Hong Kong Supreme Court and the British Council' (McDonogh \& Wong, 2001: 17). Pacific Place conforms to the design features of typical enclosed malls, including architectonics for maximum exposure to products and inducement to spend. There is a distinct modernist style to both the inner space and the facades of the three structures that comprise the complex (hotel, offices, housing, and ERC). This enclosed space should, however, be read in context. Relative to the shopping streets around the mall, the indoor space of the mall offers an experience of flanerie that, somewhat paradoxically, is not available in the otherwise eminently walkable city. This includes a controlled climate (temperature, humidity, and odour), obstruction-free walking (i.e., fewer people and no maintenance or construction-related artefacts), and the option of comfortable, leisurely windowshopping. In addition, 'live piano performance and special music programs fill the mall with a relaxing ambience for shopping' (Swire Properties, 1999).

Consumption patterns. In the Pacific Place website, a slogan claims that, '[m]uch more than a mall, Pacific Place is a true entertainment and retail destination' (Pacific Place 2007). This statement explicitly acknowledges this complex as an ERC. However, its leisure and consumption opportunities are not accessible to all. For instance, writing in 2001, Wong and McDonogh reported an interview with a maid who was a resident of Hong Kong since 1993. Her only visit to the cinema had been at Pacific Place-an experience she had not sought again because the HK\$ 50 ticket had been too expensive, equivalent to 'nearly $7 \%$ of her weekly salary.' There is little doubt that all sections of the Hong Kong population do not exercise the privilege of access to Pacific Place. Much like The Grove, this large, 'upscale' ERC has a specific place in the city's hierarchical organization of such spaces. An indication of this differentiation, and the image and patrons sought by Pacific Plaza, can be had from the fact that at any time all but one or two screens of the six-screen theatre at the AMC Pacific Place multiplex (formerly United Artists Pacific Place) are playing Hollywood (or other Englishlanguage) films (without dubbing, with Chinese subtitles). The Pacific Place mall was among the first in Hong Kong to house premium international fashion labels such as Prada, Giorgio Armani, Gucci, Louis Vuitton, and Chanel (to name a few) (McDonogh \& Wong, 2001). According to the Retail Tenant Directory (Trade Dimensions International, 2006) published for the US real estate industry, each of the brands named above cater to a 'high income' customer base and prefer 'upscale' co-tenants. This is an indication of the exclusive character of these brands, not only in terms of the prices of their products, but also in terms of the spaces they choose to locate in. There are, however, retail outlets of other brands in Pacific Place, which are 'lower' in the price hierarchy (and also spatially located on the lower floors of the ERC, approachable by a larger public). The ERC is anchored by two major department stores-Seibu (Japan) and Lane Crawford (Hong Kong). These department stores carry a range of products from the most exclusive to relatively affordable brands. Nonetheless, there is a huge difference in the prices one can expect to pay at the ERC as compared to out in shopping streets all over Hong Kong. Of the nearly 200 retail stores contained in Pacific Place, Kelly and Walsh is the only bookstore. The store directory lists books along with music and electronics. The stores offering accessories (shoes, bags, leather goods, jewellery, and watches), on the other hand, are the most numerous and display an impressive variety of brands, goods, and prices. This points to a culture of consumption fixated on fashion and consumer electronics, which are cornerstones of aspirational consumption.

Similarly, there is only one store for children, offering educational toys rather than essential goods. This acknowledges the low birth rate in Hong Kong-9.6 (per 1,000 population) in 2006, as opposed to 15.1 in 2003, in Los Angeles County (Government of the Hong Kong Special Administrative Region 2007; Los Angeles Almanac 2003). See Figures 1-6 for some illustrations of the issues discussed above.

\section{Results From User Surveys}

Our own analysis of ERCs in the two cities was supported by the results from the user surveys conducted online. This triangulation of results improves the validity of our research by confirming the findings from the literature review and field observations made in the two cities. The survey was divided into the sections of Land use, Transportation, Urban design, and 
Consumption patterns. Respondents were sought from among a population of individuals who had been to and used entertainment-retail centres in the two cities. The respondents were found by the 'snowball sampling' technique, beginning with the Hong Kong student associations at the researchers' home university. As noted above, the sample is biased towards students, who constitute about two-thirds of the respondents (40 of 60). We consider, however, that the bias does not adversely affect the validity of the findings as most of the questions posed were of a general nature, not focusing on the aspects that might vary significantly with the socioeconomic characteristics of the respondent. Besides, relevant statistics and valuable insights from users are presented in this subsection only as a complement to the other parts of the study.

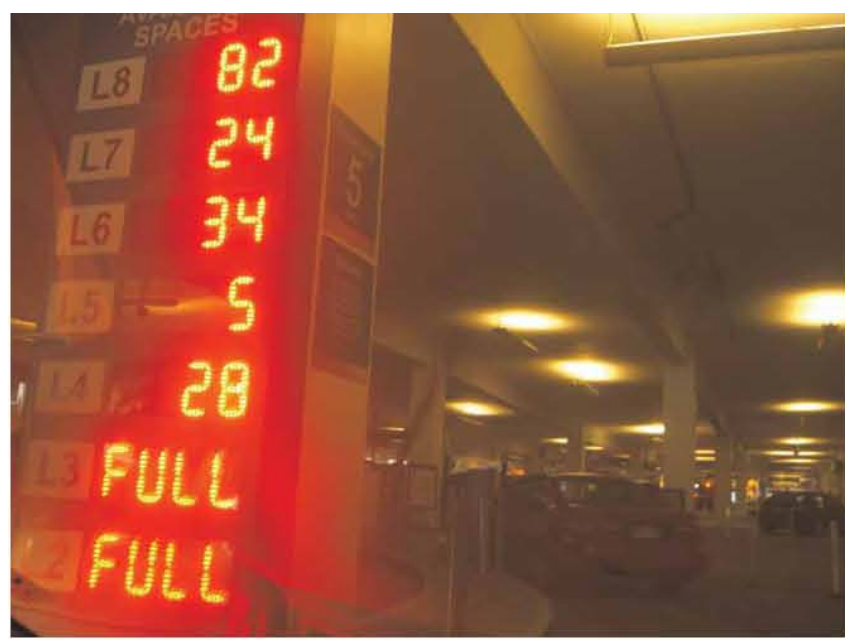

Figure 1. The Grove: parking structure filling up

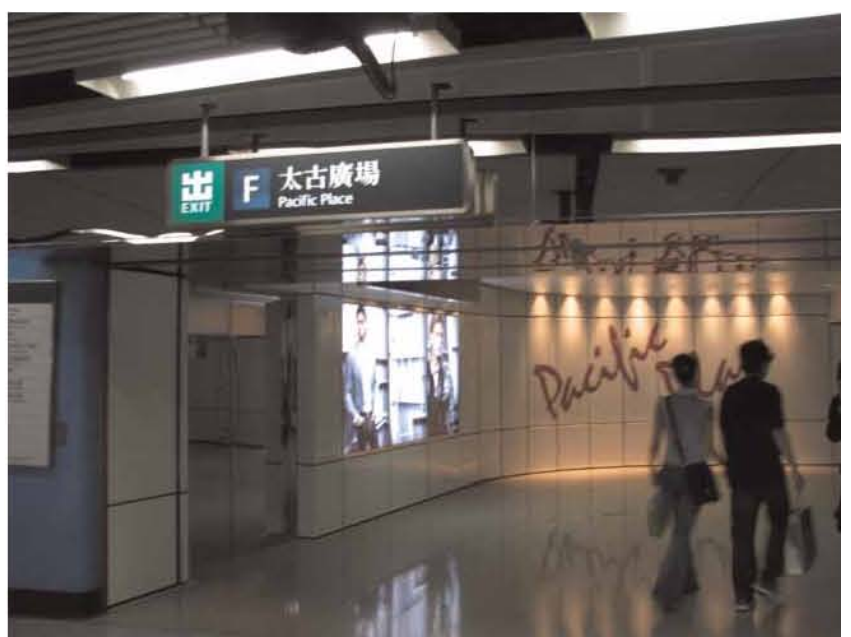

Figure 2. Pacific Place: seamlessly connected with mass transit 


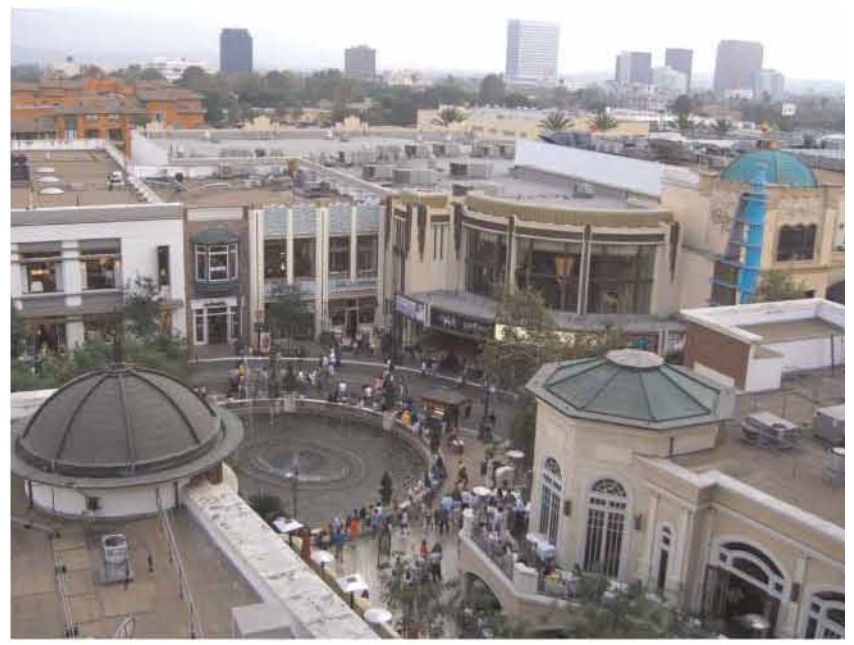

Figure 3. The Grove: facades on inward-facing buildings

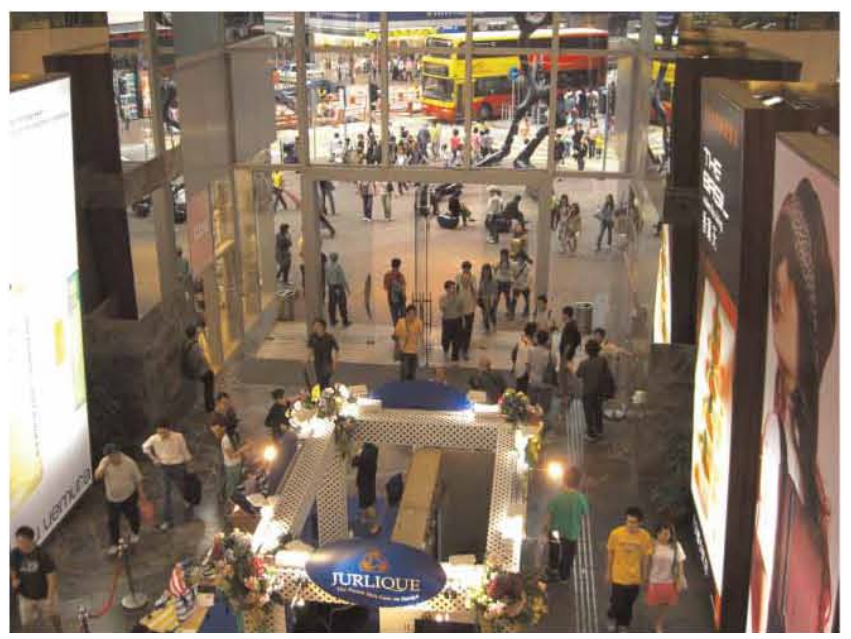

Figure 4. Hong Kong: integrated uses and indoor-outdoor movement

Land use. Ninety-six percent of the respondents believed that most or all of the ERCs in Hong Kong do a good job of blending into the existing urban fabric. Only $45.8 \%$ felt the same about Los Angeles. Additionally, $76 \%$ said ERCs in Hong Kong fitted with the surrounding community better than those in Los Angeles. Representing the frequency of commercial centres on a scale of 1 to 5 ( 1 being few, 5 being many), Hong Kong had an average score of 4.56, whereas Los Angeles had 3.17. One respondent summarized the difference as follows-'I find myself wandering into more stores in Hong Kong than Los Angeles'. The picture emerging from these responses is that Hong Kong has its commercial activity well integrated with not only the urban form but also the everyday realm of city residents. In other words, shopping is designed to be a part of daily life and both residents and businesses gain from this approach. One of our respondents captures this design approach: 'retail centers in HK are part of the community. You don't have to plan a trip there like in LA, but basically [shopping] is a part of the urban fabric there'. Los Angeles' contrasting style is aptly summarized by another respondent. 'Many retail centers in Los Angeles do not seem to consider their surroundings. . . . [and] do not weave exactly into the fabric of the surrounding community'. 


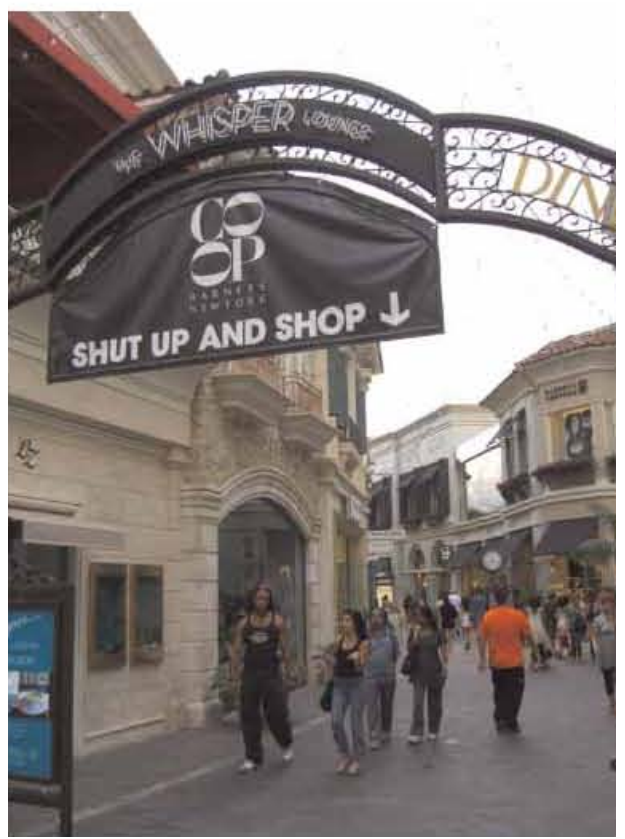

Figure 5. The Grove: historic look, contemporary feel

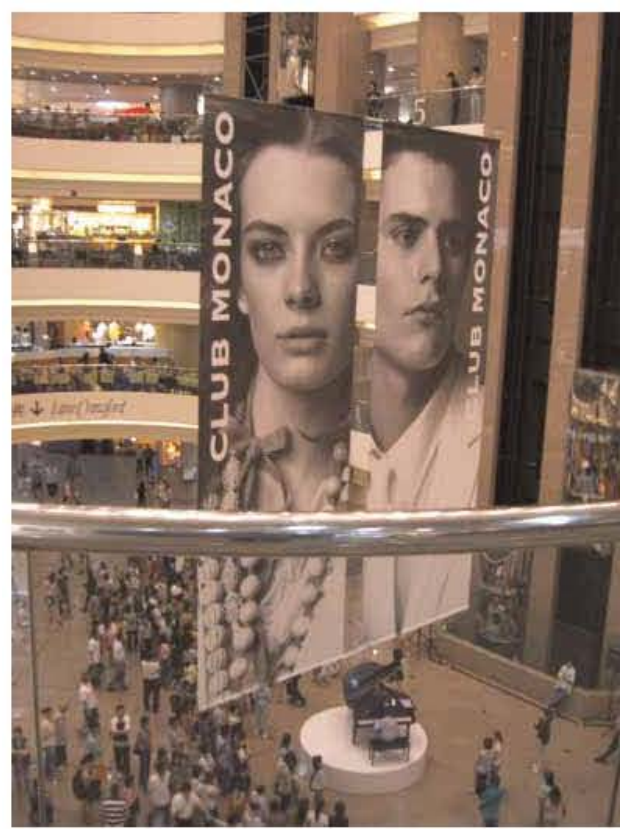

Figure 6. Hong Kong: looking west, vertical modernity

Transportation. There are some significant differences between the two cities in terms of transportation, and the survey responses put them in the context of use of ERCs. Respondents were asked how often (on a three point scale: almost never, sometimes, most of the time) they utilized each mode of transportation-private automobiles, public transit, and walking-to visit ERCs. For Hong Kong's public transit, $87 \%$ of the respondents reported using it 'most of the time'. Ninety-one percent claimed they walked at least sometimes. Additionally, 56\% replied they almost never used a private automobile to visit an ERC in Hong Kong (only 10\% saying they do so 'most of the time'). In the case of Los Angeles, on the contrary, 95\% claimed to use a private automobile 'most of the time'. Significantly, $79 \%$ and $77 \%$ 'almost never' walk or use public transit, respectively. In a related question, respondents were asked to rate the amount of pedestrian activity around the ERCs on a scale of 1 to 5 (little to heavy pedestrian activity). The average ratings were 4.8 for Hong Kong and 2.3 for Los Angeles. Respondents were also asked the distance they would be willing to travel to visit an ERC. They were asked to select from among less than 5 miles, about 5 miles, about 10 miles, about 20 miles, and more than 20 
miles. The willingness to travel about 10 miles or more was stronger in Los Angeles (92.7\%); however, as many as $65 \%$ respondents expressed willingness to travel the same distance in Hong Kong as well. This was a bit unexpected, given what we had found before regarding the high frequency of ERCs in Hong Kong and their being built into the urban fabric.

A follow-up question inquired the reason for this opinion. We received the following responses: 'It does not matter because the public transportation is convenient and fast'. 'The public transportation system makes distance almost imperceptible in HK'. 'No matter how far it is, HK's transportation makes us willing to travel to reach a retail centre'. 'Everything you need is at most 15 minutes away!' Based on these responses, we find that this willingness to travel is the result of an efficient and trusted public transit system. Users feel comfortable and assured of reaching their destination in a convenient and timely manner. Overall, $87 \%$ of the respondents felt ERCs were more accessible in Hong Kong as compared with Los Angeles. These findings are consistent with the consumer expense reports from Los Angeles and Hong Kong reported on earlier, which indicate that Hong Kongese spent $29.61 \%$ in transportation as compared with Angelinos.

Urban design. Respondents equally felt that Hong Kong does and does not have themed ERCs (such as the Universal CityWalk in LA). This could be because of an insufficient description of what we meant by 'themed'. The difference of opinion could also be on account of the seasonal themes that are characteristic of the marketing within ERCs in Hong Kong. One particularly insightful comment from among the respondents noted that, in Hong Kong, themes are divided by socio-economic classes. In other words, the exclusivity of the ERC, based on socioeconomic class, becomes the theme of the Hong Kong ERC. Eighty-four percent of respondents reported that the design of ERCs is changing in Hong Kong. Respondents were asked if openair ERCs (such as the Third Street Promenade and The Grove in LA) are becoming popular in Hong Kong. Sixty-seven percent disagreed, citing unfavourable weather conditions (subtropical hot temperatures and humidity) and high rents as reasons why this was not feasible in Hong Kong. It should be mentioned that there are several open-air traditional street markets in Hong Kong, aimed at tourists and those looking for bargains. Although these cannot be compared with the contemporary ERCs discussed here, they are an important element of the Hong Kong urban fabric and society, highlighting both the excellent accessibility within the city and the maintenance of traditions despite of rapid modernization. However, as noted before, these traditional street markets are facing development challenges on the part of public and private agents in the city that want to make these areas more profitable and 'modern' (Smith, 2007).

Consumption patterns. Survey respondents were asked why people visit ERCs in the two cities (to socialize, to shop, as a status symbol, or other reasons). The function of socializing was found to be more important in Hong Kong (87.8\% indicated socializing was the most important function in Hong Kong against $65.3 \%$ for Los Angeles). A respondent reported that 'people in $\mathrm{HK}$ enjoy spending time in shopping malls and they are great places for people to meet up as a social event. They can go there everyday, not for shopping but for hanging out.' In other words, visiting ERCs is a personal or family event in LA, whereas it is more of a broader social function in Hong Kong, i.e., one performed with friends, colleagues, or business associates. In Hong Kong, major ERCs act as meeting points for groups. Another difference is that business lunches are often held in ERCs in Hong Kong because a variety of good restaurants are usually located there that are very accessible from places of work. This is not as common in LA. Accessibility shapes consumption habits. As noted before, consumer expense reports from Los Angeles and Hong Kong indicate that Hong Kongese spent $11.24 \%$ on meals bought away from home and $0.96 \%$ on other various categories as compared with Angelinos. Respondents were also asked which category best described the average shopper in the two cities-weekly, seasonal, eventdriven, or compulsive.

Respondents were allowed to pick more than one response. The two highest responses for Hong Kong were weekly and compulsive $(69.4 \%$ and $38.8 \%$, respectively). Los Angeles shoppers were reported as event-driven and seasonal (65.3\% and $49 \%$, respectively).

In addition, one respondent expressed that, 'going to ERCs in LA has one aim-to buy, otherwise LA people won't be there'. This opinion suggests that in the use of ERCs in Los Angeles, the retail function is considered more significant in attracting customers, as compared with entertainment opportunities. Another way of interpreting this would be that in Los Angeles, 
the entertainment component of ERCs comes into play when potential patrons are selecting between comparable shopping centres. In Hong Kong, on the other hand, entertainment is more seamlessly intertwined with shopping in the quotidian experience of users.

\section{Conclusions}

The following tables (Tables 1-4) summarize the comparison of the centennial generation of ERC development in Los Angeles and Hong Kong, according to the findings gathered by the triangulated methods employed in this study and focusing on land use, transportation, urban design, and consumption patterns. As this ERC generation is not static in either city, the tables acknowledge both current features and dynamic trends of transformation.

After the technical power of controlling indoor climate and the logic of mass production and consumption were harnessed by shopping malls, styles of ERCs showed convergence in the two cities, although temporally staggered (trends arriving later in Hong Kong). Then, local contexts and the local mediation of international influences took the retail and leisure activities in different directions in both cities, as discussed in the paper. It is only in recent years with the new logic of combining entertainment and retail in highly stylized and thematized environments that ERC design has shown new points of convergence, albeit subtler than in previous eras, in these two cities. There are two main lessons to be drawn from this comparative study. First, even within the very specific topic of retail-entertainment design, evidence suggests that globalization does not simply homogenize practices and values. Although there are pressures towards homogenization in terms of the marketing strategies and location criteria of multinational corporations, a large part of a city's morphological and cultural evolution is ultimately context- and path-dependent. Both our cases are cities that operate under market institutions, are highly consumerist, and are often classified as 'post-modern' due to their postindustrial economies of flexible production and accumulation, and cultures influenced by the fashion and media industries. Even though the financial and marketing logic of combining entertainment and retail have been fully realized in both cities, the styles of ERCs in the two

Table 1. Land use

Table 1. Land use

\begin{tabular}{|c|c|c|}
\hline & \multicolumn{2}{|c|}{ Land use } \\
\hline & Los Angeles & Hong Kong \\
\hline $\begin{array}{l}\text { Urban growth } \\
\text { pattern }\end{array}$ & Sprawl, increasingly compact, infill & Compact \\
\hline $\begin{array}{l}\text { Land use pattern } \\
\text { (in urban } \\
\text { areas) }\end{array}$ & $\begin{array}{l}\text { Predominance of: } \\
\text { Single Use } \\
\text { Horizontal Development } \\
\text { Low Floor Area Ratio (FAR) } \\
\text { Large Setbacks } \\
\text { Greenfield Development } \\
\text { Increasingly mixed-use, street- } \\
\text { oriented }\end{array}$ & $\begin{array}{l}\text { Predominance of: } \\
\text { Mixed Use: Housing, } \\
\text { Commercial, Office, Public } \\
\text { Vertical Development } \\
\text { High FAR } \\
\text { Large Footprint/ Lot } \\
\text { Small, if any, setbacks. Yet } \\
\text { increasing in size }\end{array}$ \\
\hline Density & Low to medium & Very high (hyper-density) \\
\hline $\begin{array}{l}\text { ERCs' } \\
\text { connection } \\
\text { with urban } \\
\text { fabric }\end{array}$ & $\begin{array}{l}\text { Usually low: Disconnected from } \\
\text { and/or disrupting to the urban } \\
\text { fabric } \\
\text { Tending to improve conditions }\end{array}$ & $\begin{array}{l}\text { Usually High: Part of the urban } \\
\text { fabric } \\
\text { Some recent examples (mega- } \\
\text { malls) tending to worsen } \\
\text { connections }\end{array}$ \\
\hline $\begin{array}{l}\text { ERCs' role } \\
\text { within urban } \\
\text { fabric }\end{array}$ & $\begin{array}{l}\text { Usually serving as commercial } \\
\text { landmarks (community anchors) } \\
\text { and nodes of freeway } \\
\text { intersections }\end{array}$ & $\begin{array}{l}\text { Usually part of the mixed-use urban } \\
\text { fabric (common grain), or nodes } \\
\text { of transit centres } \\
\text { Increasing role as landmarks } \\
\text { (mega-projects) }\end{array}$ \\
\hline
\end{tabular}


different trajectories. It is easy to point to land scarcity in Hong Kong as the impetus for its cities have evolved along higher density and all other concomitant design features. However, geography alone does not explain why public transportation is not more popular in Los Angeles, or the city's uneasy acceptance of mixed use. Many other factors, including demographics, local urban cultures, and the interaction of public and private, local and international development interests have had significant incidence in the way these cities, and their leisure and shopping spaces, have evolved.

Second, we learn that whereas Hong Kong was catching up with the American mall phenomenon in the 1960s, it is now in some ways leading Los Angeles in the design and development of ERCs, when we account for the need to move towards more sustainable urban practices and better urban design, i.e., greater reliance on public transportation and pedestrian accessibility, more design articulation with the rest of the urban fabric, contribution to urban life in the surroundings of the ERCs, mix of uses (particularly incorporating housing), greater density, etc. And while thematically Los Angeles' current lifestyle ERCs mostly emulate European architectural styles, the traditional outdoor streets markets in Hong Kong remain a rich, almost untapped design precedent for the ongoing creation of outdoor invented and reinvented streets in the Southland region. This learning from Hong Kong (and from Asia in more general terms) may prove particularly appropriate when the Asian and Asian-descent population in Southern California is rising rapidly. Furthermore, Both the Hong Kongese models (the 'modern' multiuse ERCs and the 'traditional' street markets) can also prove culturally fit for the growing Latino population in Southern California (and the rest of the US), which in general is culturally-inclined to enjoy compact, mixed use development, public spaces, and street markets (Iraza'bal \& Farhat, 2007; Iraza'bal \& Go'mez-Barris, 2006).

Table 2. Transportation

Table 2. Transportation

\begin{tabular}{|c|c|c|}
\hline & \multicolumn{2}{|c|}{ Transportation } \\
\hline & Los Angeles & Hong Kong \\
\hline Road infrastructure & $\begin{array}{l}\text { Extensive and modern } \\
\text { Extensive network of freeways } \\
\text { Relatively stable, reaching } \\
\text { saturation } \\
\text { Deficient maintenance and } \\
\text { upgrading }\end{array}$ & $\begin{array}{l}\text { Modern, built to capacity in } \\
\text { urban areas } \\
\text { Freeways are only one } \\
\text { component of a multimodal } \\
\text { transport system }\end{array}$ \\
\hline $\begin{array}{l}\text { Dependency on private } \\
\text { vehicle to access ERCs }\end{array}$ & High & $\begin{array}{l}\text { Low, } 11 \text { million passenger-trips } \\
\text { per day by public transport in a } \\
\text { city of over } 6 \text { million }\end{array}$ \\
\hline Transit infrastructure & $\begin{array}{l}\text { Relatively poor, but improving, } \\
\text { becoming multi-modal }\end{array}$ & $\begin{array}{l}\text { Extensive, multi-modal, highly } \\
\text { networked }\end{array}$ \\
\hline $\begin{array}{l}\text { Location of ERCs in } \\
\text { relation to transit } \\
\text { stations }\end{array}$ & $\begin{array}{l}\text { Moderately correlated, } \\
\text { increasing correlation }\end{array}$ & Greatly Correlated \\
\hline $\begin{array}{l}\text { Dependency on transit } \\
\text { access to ERCs }\end{array}$ & Low, but slightly growing & High \\
\hline $\begin{array}{l}\text { Pedestrian environment } \\
\text { around ERCs }\end{array}$ & $\begin{array}{l}\text { Mostly unfriendly, clusters of } \\
\text { change (increasing pedestrian } \\
\text { friendliness) }\end{array}$ & $\begin{array}{l}\text { Mostly friendly, yet crowded } \\
\text { (insufficient). Enhancements } \\
\text { mostly due to safety issues and } \\
\text { done by government }\end{array}$ \\
\hline $\begin{array}{l}\text { Pedestrian accessibility to } \\
\text { ERCs }\end{array}$ & $\begin{array}{l}\text { Moderate: Mostly pedestrian- } \\
\text { disconnected, yet increasing } \\
\text { pedestrian connectivity }\end{array}$ & $\begin{array}{l}\text { High: Integrated and within } \\
\text { walking accessibility for } \\
\text { neighbouring residents and } \\
\text { transit users }\end{array}$ \\
\hline $\begin{array}{l}\text { Road accessibility to } \\
\text { ERCs }\end{array}$ & $\begin{array}{l}\text { High: Mostly linked to regional } \\
\text { freeways or intersections } \\
\text { thereof }\end{array}$ & $\begin{array}{l}\text { High: Mostly linked to transit } \\
\text { routes }\end{array}$ \\
\hline
\end{tabular}


Table 3. Urban Design

Table 3. Urban design

\begin{tabular}{|c|c|c|}
\hline & \multicolumn{2}{|c|}{ Urban design } \\
\hline & Los Angeles & Hong Kong \\
\hline Form & $\begin{array}{l}\text { Neo-traditional (e.g., Paseo } \\
\text { Colorado) or Neo-LA vernacular } \\
\text { (collage, pastiche, media rich, e.g., } \\
\text { Hollywood \& Highland) } \\
\text { Detached, green- or brown field } \\
\text { development, increasingly infill/ } \\
\text { refill } \\
\text { 'Invented' or 'reinvented' open-air } \\
\text { pedestrian streets }\end{array}$ & $\begin{array}{l}\text { Relatively standard exteriors, } \\
\text { increasingly high-teach façades } \\
\text { with media displays } \\
\text { Functional, vertical interior design } \\
\text { Attached, refill or (water) } \\
\text { reclamation development } \\
\text { Enclosed malls or reinvented } \\
\text { streets } \\
\text { Contemporary development in } \\
\text { most new towns based on towers } \\
\text { on large open areas }\end{array}$ \\
\hline $\begin{array}{l}\text { Architectural } \\
\text { style }\end{array}$ & Late-modern to post-modern, eclectic & $\begin{array}{l}\text { Modern, international style, } \\
\text { increasingly post-modern (themed, } \\
\text { historicized) }\end{array}$ \\
\hline Theming & $\begin{array}{l}\text { Highly themed: (European) urban } \\
\text { village (e.g., The Grove); } \\
\text { romanticized LA past (e.g., Paseo } \\
\text { Colorado); post-modern LA } \\
\text { metaphors (e.g., Hollywood \& } \\
\text { Highland, CityWalk). Increasing } \\
\text { ethnicization (e.g., Plaza Mexico) }\end{array}$ & $\begin{array}{l}\text { High receptivity to Western and } \\
\text { Chinese stylistic influences } \\
\text { Increasingly themed (Festival } \\
\text { Walk, The Maritime Square) } \\
\text { LA and California as theming/ } \\
\text { naming references (SoHo) } \\
\text { Minimal regulatory controls }\end{array}$ \\
\hline Urban grain & $\begin{array}{l}\text { Usually larger than average urban } \\
\text { fabric grain, yet increasingly } \\
\text { articulated (Paseo Colorado, The } \\
\text { Grove) }\end{array}$ & $\begin{array}{l}\text { Usually similar to average urban } \\
\text { fabric grain, tending to increase in } \\
\text { size (newer mega-malls and } \\
\text { developments in new towns) }\end{array}$ \\
\hline $\begin{array}{l}\text { Urban } \\
\text { interface: } \\
\text { façade } \\
\text { design }\end{array}$ & $\begin{array}{l}\text { Usually minimal interaction with city } \\
\text { streets } \\
\text { Improving interfaces }\end{array}$ & $\begin{array}{l}\text { No unifying façade design guidelines } \\
\text { Usually interaction with city } \\
\text { streets (open, urban façades, open- } \\
\text { space 'gestures') } \\
\text { Some worsening interfaces due to } \\
\text { maximization of leasable retail } \\
\text { space }\end{array}$ \\
\hline $\begin{array}{l}\text { ERCs' life } \\
\text { orientation }\end{array}$ & $\begin{array}{l}\text { Mostly inward-living (The Grove), } \\
\text { some increasing urban connections } \\
\text { (Paseo Colorado) }\end{array}$ & $\begin{array}{l}\text { Usually interior life connected with } \\
\text { (continuation of) lively streets } \\
\text { Newly developed ERCs are more } \\
\text { inward looking }\end{array}$ \\
\hline Programme & $\begin{array}{l}\text { Mostly US brands } \\
\text { More eclectic combination of } \\
\text { entertainment, dinning, and retail } \\
\text { Night life offerings } \\
\text { 'Street' performances } \\
\text { Multifunctional, } \\
\text { multigenerational, and } \\
\text { multicultural: varied offerings for } \\
\text { different types of people: places } \\
\text { for 'hanging out,' resting, people } \\
\text { watching }\end{array}$ & $\begin{array}{l}\text { Increasing mix of brands and chains } \\
\text { from US, Europe, and Asia } \\
\text { Increasing combination and } \\
\text { offerings of entertainment, dining, } \\
\text { and retail } \\
\text { Growing interest on lifestyle and } \\
\text { personal care offerings (health } \\
\text { spas, beauty parlours, etc.) }\end{array}$ \\
\hline
\end{tabular}


Table 4. Consumption patterns

\begin{tabular}{|c|c|c|}
\hline & \multicolumn{2}{|c|}{ Consumption patterns } \\
\hline & Los Angeles & Hong Kong \\
\hline $\begin{array}{l}\text { Consumer } \\
\text { markets }\end{array}$ & $\begin{array}{l}\text { High segmentation, specialization } \\
\text { and ethnicization of markets }\end{array}$ & $\begin{array}{l}\text { Mix of markets, increasing } \\
\text { segmentation and specialization }\end{array}$ \\
\hline $\begin{array}{l}\text { Consumption } \\
\text { patterns }\end{array}$ & $\begin{array}{l}\text { Broad range of long established } \\
\text { consumptive patterns: from basic } \\
\text { functional to lavishly hedonistic } \\
\text { consumption }\end{array}$ & $\begin{array}{l}\text { Traditional subsistence consumption } \\
\text { Range of newly established } \\
\text { consumptive patterns } \\
\text { Increasing hedonistic } \\
\text { consumption patterns }\end{array}$ \\
\hline Frequency & $\begin{array}{l}\text { Weekly, seasonal, or event-driven } \\
\text { ERCs not particularly linked to } \\
\text { everyday-life routines }\end{array}$ & $\begin{array}{l}\text { In addition to time cycles, there is } \\
\text { more compulsive shopping } \\
\text { (linked in part to greater everyday } \\
\text { exposure to market places) } \\
\text { Increasing promotion/ } \\
\text { acceptance of Western } \\
\text { commercial seasons (e.g., } \\
\text { Halloween, Christmas) }\end{array}$ \\
\hline $\begin{array}{r}\text { Consumer } \\
\text { identity }\end{array}$ & $\begin{array}{l}\text { Consumption mostly linked to the } \\
\text { maintenance of social status } \\
\text { Status is mix-based on cultural, } \\
\text { economic, and educational capital } \\
\text { Generally moderate self- and } \\
\text { fashion-consciousness and } \\
\text { sensitivity to fashion plus marked } \\
\text { polarized sectors }\end{array}$ & $\begin{array}{l}\text { Consumption greatly linked to } \\
\text { ongoing quest for self, city, and } \\
\text { national identities } \\
\text { Endeavour to enhance status } \\
\text { Status mostly economically based } \\
\text { High self- and fashion- } \\
\text { consciousness and sensitivity to } \\
\text { fashion (inside the HK CBD) }\end{array}$ \\
\hline $\begin{array}{c}\text { City image } \\
\text { project }\end{array}$ & $\begin{array}{l}\text { City-centred: LA as a micro-cosmos, } \\
\text { different worlds as part of LA } \\
\text { Identity long linked to and drawn } \\
\text { from nation state (being } \\
\text { American) }\end{array}$ & $\begin{array}{l}\text { World-oriented: HK as } \\
\text { cosmopolitan, } \\
\text { HK as part of the world } \\
\text { Increasing contestation/ } \\
\text { commoditization of Chinese } \\
\text { identity } \\
\text { Identity in flux, just recently } \\
\text { linked to nation state (being } \\
\text { Chinese) }\end{array}$ \\
\hline $\begin{array}{l}\text { Commodity } \\
\text { preferences }\end{array}$ & $\begin{array}{l}\text { Broad spectrum from ephemeral to } \\
\text { lasting commodities } \\
\text { Main buying constraints: budget } \\
\text { and travel time }\end{array}$ & $\begin{array}{l}\text { Ephemeral commodities: food, } \\
\text { entertainment, beauty services } \\
\text { and products, collectibles, } \\
\text { clothing and accessories } \\
\text { Main constraints: budget and } \\
\text { storage space }\end{array}$ \\
\hline
\end{tabular}

Paradoxically, Hong Kong and other Asian cities are moving away from the latter historic, vernacular design model in their attempts to embrace more 'modern' and profitable ones. As the ultimate irony, some new mega-malls are theming their indoor spaces as outdoor 'traditional' streets. In sum, the three most important principles recommended for Los Angeles based on the Hong Kong examples are planning for mixed use and greater density, encouraging public transit and pedestrian friendliness, and thinking strategically about the entire city. The last of these lessons refers to a need for sharing services and the positive (and negative) externalities of development equitably among all parts of the city, so that pockets of poorly serviced areas are not left behind in the city. It can be argued that this is taken care of best by the market-led real estate development. As evidenced in Hong Kong, however, active planning choices can be made in favour of integrated land uses and transportation choices, and public-private partnerships, so that development is relatively evenly distributed and well articulated with the 
existing fabric. These are principles closely related to smart growth strategies.

Conversely, planners, designers, and developers of Hong Kong's ERCs can conceptually adapt some features from the Los Angeles' centennial ERC generation in regards to the creation of more spatial opportunities for socialization within the ERCs, by expanding their sense of place and 'publicness' by design. While embracing the outdoor model, now prevalent in Los Angeles, is impractical in Hong Kong, the city's ERC design can certainly be more generous in the way the complexes interface with the urban fabric and layout their circulation and gathering spaces, both outside and inside the complexes. While developers in the US are learning from the failing indoor malls to adjust to the newer public demands for more quality experiences in the new spaces of entertainment and consumption, China's ERC development continue to be dominated by Taiwanese, Thai, and off-shored Chinese firms interested in maximizing leasable square footage in detriment of space quality (Leibowitz, 2004). As famous Southern California-based architect Jon Jerde (designer of CityWalk and other successful ERCs in the region) and other successful ERC international designers have acknowledged, in China, 'the first generation of shoppers empowered by the economic boom want 'big shiny boxes', the same unimaginative, faux-luxurious consumer palaces that Japan, Singapore and Taiwan have enjoyed for years, selling designer brands that until recently mainlanders could only dream about' (Leibowitz, 2004: np). However, this is not quite the situation for Hong Kong, which, because of its distinct past from the mainland, can now be well-positioned to lead China and other Asian countries towards more human- and urban-friendly ERC designs, without detriment to either their local cultural styles or levels of profitability. Mixed use has long been accepted as an integral component of smart growth. The case of Hong Kong, and in particular the latest generation of ERCs, shows how this can be done without compromising profitability and to the mutual benefit of all land uses.

Public transit is a sector where Los Angeles is particularly deficient. The city needs to wake up to the negative externalities of its car-dependence and look for innovative practices such as market segmentation for public transit, shuttle services, and shared cars and taxis. It should also work with incentives and disincentives to encourage less use of private cars. Recently, efforts of the city planning commissions and departments of Los Angeles and other key cities in the region (e.g., Santa Monica, Pasadena, and San Fernando), together with regional planning proposals from the Southern California Association of Governments (SCAG) are moving the area towards more compact, transit- and pedestrian- friendly, regional development. However, a decentralized planning culture and interest-group politics in the region makes progress difficult. Although Hong Kong presents a more centralized planning culture, planning has also existed within a free market framework and development has been largely led by the interests of the real estate industry. Nevertheless, Hong Kong's transit-oriented ERCs present a good example of public-private and cross-sectoral cooperation, which cannot simply be ascribed to geographical contingency.

We conclude by suggesting that the next generation of ERCs will see the entertainment component grow significantly in both cities. Additionally, we are starting to see spaces designed so that retail becomes entertainment. This includes themed and performative spaces to a greater extent than seen in The Grove.8 Based on recent trends we also predict a growing number of ERCs in these and other cities, as older shopping malls, underutilized lots (grayfield, infill, and water-reclamation development), and some public spaces (mostly underused parks and plazas) become converted into new mixed use facilities that include entertainment and retail. This growth will continue to capitalize on the trends of privatization of public spaces, urban cultures of fear (of city dangers, terrorism, and otherness), and greater segmentation of markets (which have recently included lower-income ethnic groups, previously uncatered for by ERCs). We hope that Los Angeles will consider ERC design layouts and programmes that will not entirely segregate different sectors of the community from each other, and that the public character of such spaces will be respected by its developers and managers. It is necessary to avoid letting ERCs become pseudoplaces, or 'ambiguous spaces' (Cuthbert \& McKinnell, 1997), which exist as a mask on a process that basically reproduces and reifies the social hierarchy.

Instead, ERCs could be explicitly conceived as instruments to maintain and foster social cohesion and a real civic life. On the other hand, and learning from the public involvement processes that Caruso and other ERC developers in Los Angeles are fostering, planners and developers in Hong Kong can increase efforts to approach the community, particularly the 
hitherto less recognized groups-low income families, the elderly and immigrant communitiesfor their input regarding the overall development of the city. Identifying, acknowledging, and consulting a diverse group of stakeholders can bring a greater degree of approval and legitimacy to both Los Angeles and Hong Kong planning institutions and development plans. This need is brought into sharp relief in Hong Kong with the news of street markets disappearing from the city (Smith, 2007). ERC design in Hong Kong would also do well in heeding the city's well-crafted urban design guidelines (Planning Department Hong Kong SAR Government, 2002).

As service economies and consumer cultures expand in cities throughout the world, the booming phenomenon of ERC development is bound to continue growing and evolving.

The implication of this growth and evolution will go beyond impacting (and being impacted by) land use, transportation, urban design, and consumption patterns in particular cities, including the shaping of who we are as city dwellers in a global world. It is critical that planners, designers, developers, policymakers, and urban scholars pay close attention.

\section{Acknowledgements}

The authors would like to thank the Lusk Center for Real Estate at the University of Southern California for their funding which make this study possible. We would also like to thank Professor Shui Yang Tang. Professor Mee Kam Ng, Professor Eric Heikkila, and all the interviewees for their helpful participation at various stages of the project. We do retain, however, all responsibility of the final paper.

\section{Notes}

1. The purpose of this paper is not to dissect this globalization dynamic, but rather to focus on the planning and design of entertainment-retail centers. For an overarching discussion of global processes' impact on urban development, refer to Borja \& Castells, 1997; Castells, 2000; Harvey, 2006a, 2006b; Sassen, 2006; and Goldin \& Reinert, 2007; among others.

2. The term 'convergence' has been used to refer to the idea of nations and cities becoming similar in the global era in regards to their built environments (Iraza'bal, 2003;Williamson, 1996) and also in other ways, including policy (Drezner, 2001), organizational change (Guillen, 2002), economic institutions (Radice, 2000), and consumption patterns (Ko'nya \& Ohashi, 2004). In general, the identified trends of convergence are primarily driven by global economic, political, and cultural conditions (including policies, institutions, and values becoming similar). The term also holds a less explicit suggestion of 'westernization' of the global 'south' through the guiding principles of 'Anglo-Saxon' neoliberalism' (Radice, 2000: 720). In this study we do not concern ourselves with the macroeconomic or political significance of convergence. Although its various meanings are undoubtedly related, references to convergence here imply an exploration of the degree by which planning, design, and consumption patterns related to ERCs become similar or dissimilar in these two cities studied.

3. We have made corrections for our sample bias at every level, by using triangulation as the key to our methodology. The majority of sample respondents are Hong Kongese students, young, and well-off. However, (a) although in fewer numbers, Americans were represented. Moreover both researchers are themselves more familiar with the US case, and this condition, along with the other research methods used, relatively compensates the sample bias. (b) Young people are very representative of the users of the malls. (c) Older, non-student people also took the survey, and no marked differences were found in their responses vis-a'-vis others. In fact, our participant observations showed that families also shopped in most malls, and that a marked segregation of space by teenagers and families did not exist. Instead, the segregation mostly existed between different market niches (by class, lifestyle, ethnicity, etc.). The survey is thus one more method that we balance out with the rest (including literature review, expert interviews, and participant observation). Survey responses-particularly open-ended question inquiring the reason for the responses-helped us to arrive at a thick understanding of some issues based on repeated themes. Furthermore, we have made very limited quantitative assertions and only present the statistical evidence as complementary to the other dimensions of our research.

4. For the categories outside of retail and entertainment, Angelinos spent approximately $80.27 \%$ of their budget, as follows: housing $(37.1 \%)$, transportation $(18.7 \%)$, personal insurance and pensions $(9.1 \%)$, food at home $(6.77 \%)$, health care $(4.3 \%)$, cash contributions $(2.6 \%)$, and education $(1.7 \%)$. For the categories outside of retail and entertainment, Hong Kongese spent $51.93 \%$ of their budget, as follows: housing $(32.76 \%)$, transportation

$(9.09 \%)$, and food at home (10.08\%).Thiswould growto $68.08 \%$, assuming that 'miscellaneous services' $(16.15 \%)$ encompasses health care, childcare, education, and insurance expenses, which are otherwise unaccounted for in the expense breakdown. In sum, for the categories outside of retail and entertainment, Hong Kongese spent $24.34 \%$ in housing, $29.61 \%$ in transportation, and $\mathbf{3 . 3 1 \%}$ in food at home as compared to LA. Households in the Los AngelesRiverside-Orange County, California metropolitan area spent an average of US\$47,459 per year in 2001-2002, about 18 percent more than the typical US household. Conversely, a household in Hong Kong spent on average HK\$18,900 per month (US $\$ 2,415.42$; 1 US $\$ 1 / 47.8247$ HK\$) on consumption items in 2004/05.

5. Some of the reasons fort this include rising disposable incomes for many, easy access to higher-end goods, rising eminence of the pursue of fashion in decision-making, availability of cheaper products with greater choice, changing values, co-option of public space by retail use, and the creation of aspirational consumers (with the help of mass media).

6. Defined as '[c]enters of over 300,000 square feet each' (Hanchett, 1996: 1098). 
7. The lawwas passed under theEisenhower administrationwhen theRepublicanParty enjoyed amajority in the senate. 8. For example, the newer Nike (Nike towns) and other sporting brand stores have sophisticated stage-setting designs that incorporate media displays and activities such as rock climbing.

\section{References}

Banerjee, T. (2001) Beyond invented streets and reinvented places, Journal of the American Planning

Association, 67(1), pp. 9-24.

Banerjee, T., Giuliana, G. et al. (1996) Invented and reinvented streets: Designing the new shopping experiene, Lusk Review, 2 (1), pp. 18-30.

Beaverstock, J. V., Smith, R. G. \& Taylor, P. J. (2000) World-city network: a new metageography? Annals of the Association of American Geographers, 90(1), pp. 123-134.

Beyard, M. D. (Ed) (2001) Developing Retail Entertainment Destinations (Washington D.C: Urban Land Institute).

Borja, J. \& Castells, M. (in collaboration with M. Belil \& C. Benner) (1997) Local and Global: The Management of Cities in the Information Age (London: Earthscan Publications).

Bristow, R. (1989) Hong Kong's New Towns: A Selective Review (Hong Kong: Oxford University Press).

Caruso Affiliated (2006) Development: The Grove. Available at http://www.carusoaffiliated.com/development/ (accessed 26 August 2006).

Castells, M. (2000) The Rise of the Network Society. The Information Age: Economy, Society and Culture, I (Oxford: Blackwell).

Castells, M. (2005) Space of flows, space of places: materials for a theory of urbanism in the information age, in B. Sanyal (Ed.) Comparative Planning Cultures, pp. 45-66 (New York: Routledge).

Chase, J. (1991) The role of consumerism in American architecture, Journal of Architectural Eduction, 44 (4), pp. $211-$ 224.

Cohen, L. (1996) From town center to shopping center: The reconfiguration of community marketplaces in postwar America, The American Historical Review, 101(4), pp. 1050-1081.

Crawford, M. (2002) The World in a shopping mall, in M. Sorkin (Ed) Variations On A Theme Park: The New American City And The End Of Public Space, pp. 3-30 (New York: Hill \& Wang).

Cuthbert, A. R. \& McKinnell, K. G. (1997) Ambiguous space, ambiguous rights: Corporate power and social control in Hong Kong, Cities, 14(5), pp. 295-311.

Davis, S.G. (1999) Space Jam: media conglomerates build the entertainment city, European Journal of

Communication, 14(4), pp. 435-459.

Drezner, D.W. (2001) Globalization \& policy convergence, International Studies Review, 3(1), pp. 53-78.

Emporis Buildings (2007) Three Pacific Place. Available at http://www.emporis.com/en/wm/bu/?id1/4 3pacificplacehongkong-china (accessed 4 April 2007).

Fainstein, S. S. \& Judd, D. R. (1999) The Tourist City (New Haven: Yale University Press).

Fainstein, S. S., Stokes, R. J. (1998) Spaces for play: The impacts of entertainment development on New York City. Economic Development Quarterly, 12(2), pp. 150-165.

Goldin, I. \& Reinert, K. (2007) Globalization for development: trade, finance, aid, migration, and policy (Rev. edn) (Washington, DC: World Bank; Basingstoke, New York: Palgrave Macmillan).

Goodwin, N., F. Ackerman \& D. Kiron (Eds) (1997) The Consumer Society (Washington DC: Island Press).

Goss, J. (1993) The 'Magic of the Mall': An analysis of the form, function and meaning in the contemporary retail built environment, Annals of the Association of American Geographers, 83(1), pp. 18-47.

Gottdiener, M. (1997) The Theming of America (Boulder, CO: Westview).

Government of the Hong Kong Special Administrative Region. (2007) Hong Kong in Figures, 2007 Edition. Available at http://www.censtatd.gov.hk/FileManager/EN/Common/hkinf.pdf (accessed 24 July 2007).

Government of the Hong Kong Special Administrative Region. (2005) 2004/05 Household Expenditure Survey and the Rebasing of the Consumer Price Indices. Census \& Statistics Department (C\&SD). Available at http://www.statisticalbookstore.gov.hk/en/index.html (accessed 24 July 2005).

Guillen, M. (2002) The Limits of Convergence: Globalization and Organizational Change in Argentina, South Korea and Spain (Princeton: Princeton University Press).

Habermas, J. (1989) The Structural Tranformation of the Public Sphere (Cambridge: Polity Press).

Hanchett, T.W. (1996) US Tax Policy and the shopping center boom of the 1950s and 1960s, The American Historical Review, 101(4), pp. 1082-1110.

Harvey, D. (2006a) Spaces of global capitalism: towards a theory of uneven geographical development (London, New York, NY: Verso).

Harvey, D. (2006b) The Limits to Capital (New Ed) (London, New York: Verso).

Huang, T.M. (2004) Walking Between Slums and Skyscrapers: Illusions of Open Space in Hong Kong, Tokyo, and Shanghai (Hong Kong: Hong Kong University Press).

Irazábal, C. (2003) Ultrapassando o debate entre converge^ncia e diverge^ncia urbanas: a arquitetura e o urbanismo em um contexto global, Cadernos IPPUR, XVII(1), pp. 111-132.

Irazábal, C. (2007a) Diasporic, Bounded Tourism: The Invention and Commodification of Traditions for Locally- Bound Mexicans in Plaza Mexico. Paper presented at the Latin American Studies Association (LASA) Conference. Montreal, Canada. October.

Irazábal, C. (2007b) Kitsch is dead, long live Kitsch: the production of Hyperkitsch in Las Vegas, Journal of Architectural and Planning Research, 24(3), in press.

Irazábal, C. and M. Go'mez-Barris. (2006) Latino New Urbanism in Los Angeles. Paper presented at the Latin American Studies Association (LASA) Conference. San Juan, Puerto Rico. March.

Irazábal, C. and R. Farhat. (2007) Latino communities in the United States: a synthesis of the literature relevant to planning, Journal of Planning Literature, 22(3).

Jackson, K.T. (1996) All the world's a mall: Reflections on the social and economic consequences of the American shopping center, The American Historical Review, 101(4), pp. 1111-1121.

Jacobs, J. (1961) The Death and Life of Great American Cities (New York: Random House).

Kohn, M. (2004) Brave New Neighborhoods: The privatization of public space (New York: Routledge). 
Kónya, I. \& Ohashi, H. (2004) Globalization and Consumption Patterns among the OECD Countries. Boston College's Working Papers in Economics. Available $\begin{array}{llllll}\text { http://escholarship.bc.edu/cgi/viewcontent.cgi?article1/41022\&context1/4econ_papers } & & & \\ \text { Leibowitz, E. } & \text { (2004) The Great Mall of China. Time April } & \text { 26. Available at }\end{array}$ http://www.time.com/time/magazine/article/0,9171,629436,00.html (accessed 24 July 2007). Liang, C. (1973) Urban Land Use Analysis: A Case Study on Hong Kong (Hong Kong: Ernest Publications). Lo, C.P. (1992) Hong Kong (London: Belhaven Press).

Longstreth, R. (1998) City center to regional mall: Architecture, the automobile, \& retailing in Los Angeles, 1920-1950 (Cambridge: MIT Press).

Los Angeles Almanac. (2003) Live Births and Birth Rates, 2003 Los Angeles County and California (data from the CA Dept. of Health Services) Available at http://www.laalmanac.com/vitals/vi06.htm (accessed 24 July 2003).

Lui, T. (2001) The malling of Hong Kong. In Mathews, G. and Lui, T. (Eds) Consuming Hong Kong, pp. 23-45 (Hong Kong: Hong Kong University Press).

Maitland, B. (1990) The New Architecture of the Retail Mall (London: Architectural Design and Technology Press).

Mathews, G. and Lui, T. (Eds) (2001) Consuming Hong Kong (Hong Kong: Hong Kong University Press).

McDonogh, G. \& Wong, C. (2005) Global Hong Kong (New York: Routledge).

Mitchell, D. (2003) The Right to the City: Social Justice and the Fight for Public Space (New York: The Guilford Press).

Ng, M.K. (2005) Planning cultures in two Chinese transitional cities: Hong Kong and Shenzhen, in B. Sanyal

(Ed.) Comparative Planning Cultures, pp. 113-144 (New York: Routledge).

Ng. M.K. (1999) Political economy and urban planning: A comparative study of Hong Kong, Singapore and Taiwan, Progress in Planning, 51(1), pp. 1-90.

Pacific Place. (2007) Available at http://www.pacificplace.com.hk/shopping/mall/mall_index.html (accessed 24 July 2007)

Pizarro, R., Wei, L. \& Banerjee, T. (2003) Agencies of globalization and Third World Urban Form: A review, 18(2), pp. $111-130$

Planning Department Hong Kong SAR Government. (2002) Urban Design Guidelines for Hong Kong. In Association with Designscape International Limited CW Ho Associates: RMJM Hong Kong Limited. Available at http://www.pland.gov.hk/p_study/comp_s/udg/udg_es/udg_es_eng.pdf (accessed 26 July 2007).

Radice, H. (2000) Globalization and national capitalisms: theorizing convergence and differentiation, Review of International Political Economy, 7(4), pp. 719-742.

Ramsey, Mike. (2003) Shopping areas center on community: Redesigned malls give town flavor. Chicago Tribune. Nov 17, p. 8.

Russell, J. (1997) Entertainment Retail: Theming vs. Design: Fantasy architecture has a distinguished history, but marketing-driven, escapist expectations may be corroding architecture's public role. Architectural Record,

March, pp. 90-93.

Sassen, S. (1991) The Global City: New York, London, Tokyo (Princeton: Princeton University Press).

Sassen, S. (2000) Cities in a World Economy (2nd Ed.) (Thousand Oaks, CA: Sage Publications).

Sassen, S. (2002) Locating cities on global circuits. Environment and Urbanization, (14)1, pp. 13-30.

Saunders, A. (2007) Retail ghosts: The enclosed mall is a dying breed. The Columbus Dispatch. Business; Pg. 01D. July 15.

Shillingburg, D. (1994) Entertainment drives retail, Architectural Record, (182) 8, pp. 82-85.

Shuyong, L. (1997) Hong Kong: A survey of its political and economic development over the past 150 years, The China Quarterly, 151, pp. 583-592.

Smith, D. \& Timberlake, M. (2002) Hierarchies of dominance among world cities: A network approach, in S. Sassen (Ed) Global Networks, Linked Cities, pp. 117-144 (New York: Routledge).

Smith, P. (2007) At risk in Hong Kong: A slice of hawkers' magic. International Herald Tribune: Asia-Pacific. Available at http://www.iht.com/articles/2007/06/14/asia/hong.php.

So, L. Y. (2000) Conservation of traditional retail nodes in Hong Kong. Thesis in partial fulfillment for the degree of Master of Urban Design, Faculty of Architecture, University of Hong Kong. Available at http://sunzi1.lib.hku.hk/hkuto/record/B31980429 (accessed 2 April 2007).

Soja, E., Morales, R. and Wolff, G. (1983) Urban restructuring: An analysis of social and spatial change in Los Angeles, Economic Geography, 59(2), pp. 195-230.

Sterne, J. (1997) Sounds like the Mall of America: Programmed music and the architectonics of commercial space, Ethnomusicology, 41(1), pp. 22-50.

Swire Properties Ltd. (1999) Pacific Place. Available at http://www.pacificplace.com.hk/homepage.html (accessed 4 April 2007).

Taylor, P.J. (2003) World City Network: A Global Urban Analysis (London: Routledge).

Trade Dimensions International Inc. (2006) Retail Tenant Directory. Company Profiles, pp. 27-1012 (Wilton, CT: TDI Inc.).

United States Department of Labor. (2004) Consumer Spending Patterns in Los Angeles-Riverside-Orange

County, 2001-2002. Bureau of Labor Statistics. Available at http://www.bls.gov/ro9/cexlosa.htm (accessed 24 July2004).

Williamson, J. (1996) Globalization, convergence and history, The Journal of Economic History, 56(2), pp. 277-306

Wong, C.Y. and McDonogh, G.W. (2001) Consuming cinema, in G. Mathews \& T. Lui (Eds) (pp. 81-116) Consuming Hong Kong (Hong Kong: Hong Kong University Press).

Zukin, S. (1998) Urban lifestyles: Diversity and standardization in space of consumption, Urban Studies, 35(5-6), pp. 825-839. 